\title{
AN ATTEMPT TO ESTIMATE THE CURIE-POINT ISOTHERM DEPTHS IN THE NUPE BASIN, WEST CENTRAL NIGERIA
}

\section{I. NWANKWO, P. I. OLASEHINDE AND C. O. AKOSHILE}

(Received 5, November 2008; Revision Accepted 5, August 2009)

\section{ABSTRACT}

An estimate of Curie-point isotherm depths has been made in the northern part of the Nupe Basin, west of Central Nigeria, from the spectral analysis of aeromagnetic data. Curie-point, the temperature at which rocks lose their ferromagnetic properties, provides a link between thermal models and models based on the analysis of magnetic sources. The result of this study shows that the Curie isotherm depth varies between 12 and $30 \mathrm{~km}$ in the study area. In the southern portion of the study area, the curie-depth was found above $28 \mathrm{~km}$ while it was found to be less than $14 \mathrm{~km}$ in the northern part. It had previously been discovered by earlier workers that Curie-point depths are shallower than $15 \mathrm{~km}$ for volcanic and geothermal fields, between $15-25 \mathrm{~km}$ for island arcs and ridges, and deeper than $20 \mathrm{~km}$ in plateaus and trenches. Therefore, when the values for the study area are compared with these values, the areas with variations less than $15 \mathrm{~km}$ maybe recommended for further geothermal reconnaissance studies.

KEY WORDS: Curie-point Isotherm, Spectral Analysis, Aeromagnetic Data, and Nupe Basin.

\section{INTRODUCTION}

Surveys of the spatial changes in the strength of the magnetic field over the surface of the earth have been used as a method for geophysical exploration for many years (Manzella, 1999). The magnetic method has come into use for identifying and locating masses of igneous rocks that have relatively high concentration of magnetite. Magnetite is the most common ferromagnetic mineral and so, in most cases, the magnetic permeability is determined by the amounts of magnetite and related minerals present in the rock. Strong magnetic rocks include basalt and gabbro, while rocks such as granite, granodiorite and rhyolite have only moderate high magnetic susceptibility. The magnetic method is useful in mapping near-surface volcanic rocks that are often of interest in geothermal exploration, but the greatest potential for the method lies in its ability to detect the depth at which the Curie temperature is reached; i.e., the Curie-point isotherm depth. Ferromagnetic materials exhibit a phenomenon characterised by a loss of nearly all magnetic susceptibility at a critical temperature called the Curie temperature. Various ferromagnetic minerals have differing Curie temperatures, but the Curie temperature of titano-magnetite, the most common magnetic mineral in igneous rocks, is in the range of a few hundreds to $580^{\circ} \mathrm{C}$. The ability to determine the depth to the Curie point would be an ability to determine the depth to the Curie point isotherm as well.

Useful two-dimensional (2-D) techniques for spectral analysis of aeromagnetic anomalies have been described (Bhattacharyya, 1966; Spector and Grant, 1970; Shuey et. al., 1977). Bhattacharyya (1966) derived an expression for the power spectrum of the total magnetic field intensity over a single rectangular block, which was generalized by Spector and Grant (1970) by assuming that the anomalies on an aeromagnetic map are due to an ensemble of vertical prisms. They demonstrated that contributions from the depth, width and thickness of a magnetic source ensemble could affect the shape of the energy spectrum. The dominant term, which controls this shape, is depth factor. The depth estimates could be made using the equation, $E(r)=e^{-2 h r}$ (Spector and Grant, 1970; Hahn et al, 1976); where $E(r), h$ and $r$ are the spectral energy, depth and frequency respectively. The thickness factor $\left(1-e^{-t r}\right)^{2}$ plays an interesting role in shaping the power spectrum. When combined with the depth factor $\mathrm{e}^{-2 \mathrm{hr}}$ (for not too large values of $\mathrm{r}$ ), its effect is to produce a peak in the spectrum whose position shifts towards smaller wavenumbers with increasing values of $t$ (thickness). When this peak occurs (significant maximum), it indicates that the source bottoms are detectable. The frequency $f_{\max }$ of the spectral peak, the mean depth $\mathrm{h}$ to the source tops (depth to deep-seated causative bodies) and the mean depth $d$ to the source bottom (Curie depth) are related by the equation (Boler, 1978; Connard et al., 1983; Salem et al. 2000): $\mathrm{f}_{\max }=\frac{1}{2 \pi(\mathrm{d}-\mathrm{h})} \ln \left[\frac{\mathrm{d}}{\mathrm{h}}\right]$, where $\mathrm{d}=\mathrm{h}+\mathrm{t}$. Whether the sources appear to be depth limited or not depends very much on the size of the map. If there were no restrictions upon either the size of the map or size of the computer, then presumably the Curie-point isotherm could be observed. Therefore, aeromagnetic maps are useful for large-scale understanding and characterization of crustal temperatures.

The work presented here is an estimation of Curie-point isotherm in the northern part of the sedimentary Nupe Basin of West Central Nigeria from

L. I. Nwankwo, Department of Physics, University of Ilorin, Ilorin, Nigeria.

P. I. Olasehinde, Department of Geology, Federal University of Technology, Minna, Nigeria.

C. O. Akoshile, Department of Physics, University of Ilorin, Ilorin, Nigeria. 
the power spectrum analysis of the aeromagnetic data. Prior to this study there was no evidence of published Curie depth studies of the Nupe Basin. However, an estimation of the depth to the Curie-point temperature in the Upper Benue trough has been made by Nur et. al., 1999. They showed that the Curie-point isotherm in that region varies between $23.80 \mathrm{~km}$ and $28.70 \mathrm{~km}$. Also, Onuoha and Ofoegbu (1988) reconstructed the time, temperature and depth relations for sediments in the Dahomey Embayment. Their results indicate that most post-Turonian sediments have hardly been subjected to temperatures higher than $70^{\circ} \mathrm{C}$ at any time. The outcome of this study will no doubt provide a general basic framework for future detailed survey and contribute tremendously to a better understanding of the thermal and crustal structures of the Nupe basin.

\section{LOCATION, CLIMATE, VEGETATION AND GEOLOGY OF THE STUDY AREA}

The area of study, which is the northern part of the sedimentary Nupe Basin, is bounded by latitudes
$8^{0} 30^{\prime}$ and $10^{\circ} 00^{\prime}$ North and longitudes $4^{0} 30^{\prime}$ and $6^{0} 00^{\prime}$ East. It is an area of about 27,200 square kilometres situated at the West of Central Nigeria. The Nupe Basin (also known as the Middle Niger Basin or Bida basin) is an elongated NW-SE trending depression perpendicular to the main axis of the Benue Basin of Nigeria. The entire basin is bounded by latitudes $8^{\circ} 00^{\prime} \mathrm{N}$ and $10^{\circ} 30^{\prime} \mathrm{N}$ and longitudes $4^{\circ} 30^{\prime} \mathrm{E}$ and $7^{\circ} 30^{\prime} \mathrm{E}$. It covers an area of approximately $90,750 \mathrm{~km}^{2}$ (Figure 1). The area is marked by two distinct climatic conditions. The rainy season lasts usually from May/June to September/October depending on the rainfall pattern for the particular year, with mean annual rainfall of $1560 \mathrm{~mm}$. The dry season is usually heralded annually by the dry, cold Harmattan winds and occurs between November and March. After the departure of the Harmattan and in the absence of rain, the hot sunny season with temperatures exceeding $27{ }^{\circ} \mathrm{C}$ sets in (Balogun, 2003). The mean annual temperature of the area is $20^{\circ} \mathrm{C}$.

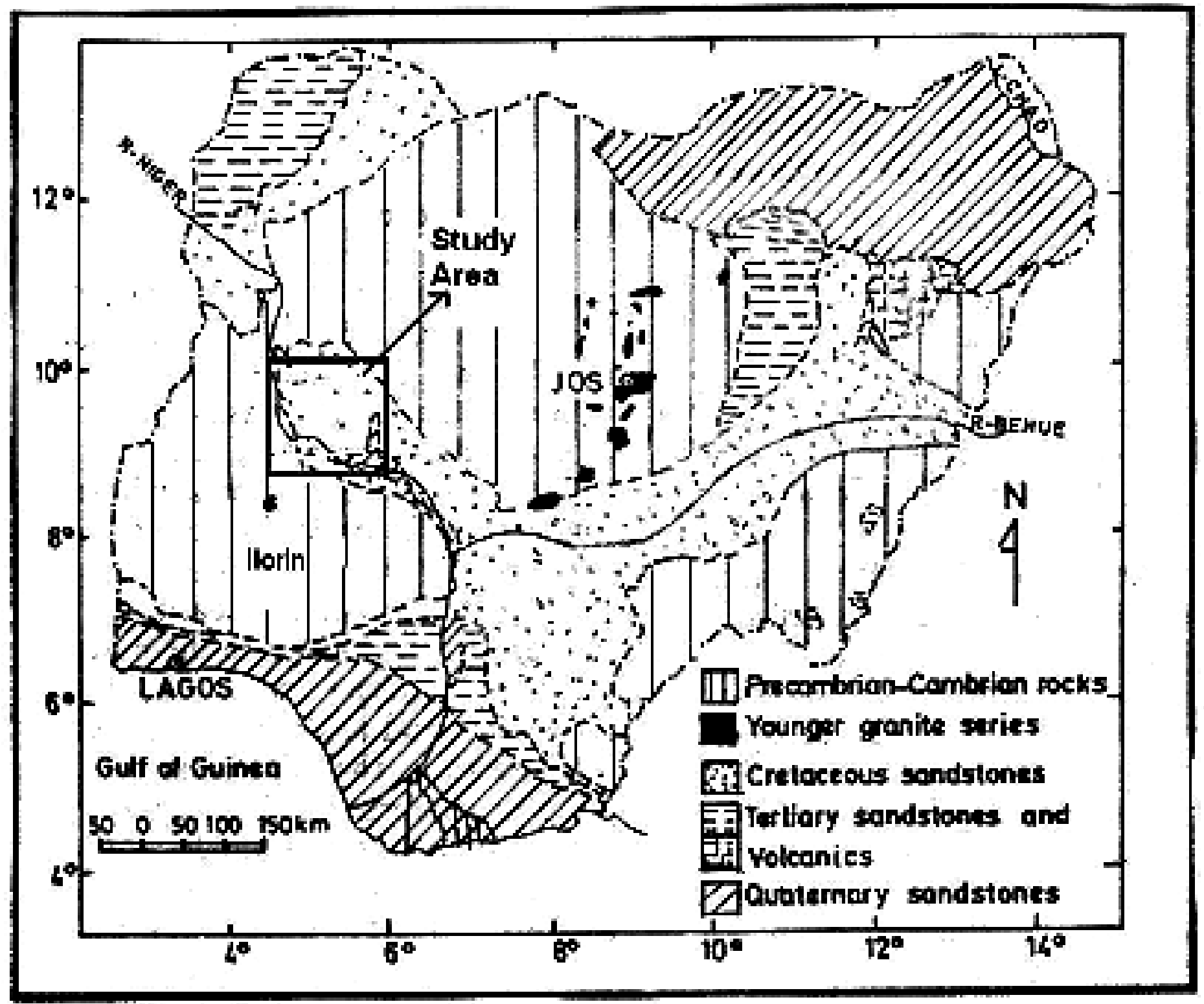

Figure1: Geological map of Nigeria showing the study area 
The vegetation, which is predominantly of the Savannah-type, is characterised by giant grasses and few trees. Short feathery grasses form an almost continuous ground cover during the wet season. The Niger River and its tributaries drain the area. The physical elevation of the study area ranges from $100 \mathrm{~m}$ above sea level around the vicinity of the River Niger and its tributaries to $300 \mathrm{~m}$ in other regions. The soil cover is mainly lithosols and alluvial along River Niger areas and its tributaries.

The Nupe Basin (Figure 1) is a gentle downwarped shallow trough filled with CampanianMaestrichtian marine to fluviatile strata. The strata are believed to be more than $300 \mathrm{~m}$ thick (Jones, 1955; Adeleye, 1971, 1973, 1974, 1976). Murat (1972) reported that the basin might be regarded as northwestern extension of the Anambra basin, which is found in the southeast, both of which were major depocenters during the second major sedimentary cycle of southern Nigeria in the Upper Cretaceous time.

\section{METHODOLOGY}

Airborne magnetometer survey maps of contours of total magnetic field intensity of sheets 160 , 161, 162, 181, 182, 183, 202, 203, and 204 published by the Geological Survey of Nigeria Agency, Airborne geophysical series (1976) on a scale of 1:1000,000 were used. The contour interval is variable at $5,10,25$ and $50 \mathrm{nT}$. The survey was carried out along a series of NE SW lines with a spacing of $2 \mathrm{~km}$ and an average flight elevation of $152 \mathrm{~m}$ above the ground level. The average magnetic inclination across the survey area was from $9^{\circ}$ in the north to $0^{\circ}$ in the south. Since one common problem in automated data interpretation is to select digitisation spacing and minimum length of data profile in order to minimize aliasing error, selecting a digitisation interval of $0.875 \mathrm{~km}$ was found to be appropriate (Khurana, 1981). Therefore, the maps were carefully digitised manually at an equal spacing of $0.875 \mathrm{~km}$ yielding 4096 values per sheet and 36,864 values for the 9 sheets used in this study. Although manual digitisation is the most elementary and least efficient method of digitisation, its accuracy when carefully done, compares favourably with other more sophisticated methods (Bath, 1974). The spacing interval of $0.875 \mathrm{~km}$ imposes a nyquist frequency of 0.57 $\mathrm{km}^{-1}$.

In view of the simplicity in the trend of the magnetic field in the survey area, the regional anomaly was removed from the observed data by fitting a plane polynomial surface to the data. The study area does not have complex geology and it has relatively small spatial extent, therefore, it seemed adequate and reasonable to assume that the regional field is a first-degree polynomial surface (plane trend) (Olasehinde, 1991). All the regional fields were, therefore, evaluated as a twodimensional first-degree polynomial surface. The expression for the regional field of the study area is therefore, calculated and given as (Nwankwo, 2006):

$g(x, y)=7836.3+0.0241 x+0.0872 y$. Residual data were then obtained as the deviations from the total intensity data from the fitted plane surface. Upward continuation technique was also utilized to suppress short wavelength components of the residual magnetic anomalies in the study area. The continuation was carried out at a height of $0.282 \mathrm{~km}$.

The study area was divided into eighty-one overlapped blocks for the purpose of spectral analysis as shown in Figure 2. Each block covers a square area of $45 \mathrm{Km}$ by $45 \mathrm{Km}$, which represents a square grid of 24 by 24 upward-continued residual field points. These were cosine-tapered before the radial spectrum was evaluated.

\begin{tabular}{|l|l|l|l|l|l|l|l|l|}
\hline 1.1 & 1.2 & 1.3 & 1.4 & 1.5 & 1.6 & 1.7 & 1.8 & 1.9 \\
\hline 2.1 & 2.2 & 2.3 & 2.4 & 2.5 & 2.6 & 2.7 & 2.8 & 2.9 \\
\hline $\mathbf{3 . 1}$ & 3.2 & 3.3 & 3.4 & 3.5 & 3.6 & 3.7 & 3.8 & 3.9 \\
\hline $\mathbf{4 . 1}$ & $\mathbf{4 . 2}$ & 4.3 & 4.4 & 4.5 & 4.6 & 4.7 & 4.8 & 4.9 \\
\hline $\mathbf{5 . 1}$ & $\mathbf{5 . 2}$ & 5.3 & 5.4 & 5.5 & 5.6 & 5.7 & 5.8 & 5.9 \\
\hline $\mathbf{6 . 1}$ & $\mathbf{6 . 2}$ & 6.3 & 6.4 & 6.5 & 6.6 & 6.7 & 6.8 & 6.9 \\
\hline $\mathbf{7 . 1}$ & $\mathbf{7 . 2}$ & 7.3 & 7.4 & 7.5 & 7.6 & 7.7 & 7.8 & 7.9 \\
\hline $\mathbf{8 . 1}$ & $\mathbf{8 . 2}$ & $\mathbf{8 . 3}$ & 8.4 & 8.5 & 8.6 & 8.7 & 8.8 & 8.9 \\
\hline $\mathbf{9 . 1}$ & $\mathbf{9 . 2}$ & $\mathbf{9 . 3}$ & $\mathbf{9 . 4}$ & $\mathbf{9 . 5}$ & $\mathbf{9 . 6}$ & $\mathbf{9 . 7}$ & $\mathbf{9 . 8}$ & 9.9 \\
\hline
\end{tabular}

Figure 2: Diagram showing overlapped blocks of the study area used for power spectral analysis. Gray numbered blocks do not have data 
Graphs of the logarithms of the spectral energies against frequencies obtained for the various blocks were obtained. Linear segment from the low frequency portion of the spectra, representing contributions from the deepseated causative bodies could be drawn from each graph. The gradient of the linear segment was evaluated and the equation (Spector and Grant, 1970; Hahn et al,

1976), $h=-\frac{m}{4 \pi}$ was used to calculate the depth to the causative bodies; where $\mathrm{m}$ is the gradient. The equation, $f_{\max }=\frac{1}{2 \pi(\mathrm{d}-\mathrm{h})} \ln \left[\frac{\mathrm{d}}{\mathrm{h}}\right]$, was consequently used to calculate the thickness and hence, the curiepoint depths.

\section{RESULTS AND DISCUSSION}

Graphs of the logarithms of the spectral energies against frequencies were obtained for the various blocks. Some of the graphs with spectral peak are shown in Figure 3. The occurrence of a significant peak in the spectrum indicates that the Curie-depths, which define the source bottoms, are detectable. Two linear segments could be drawn from each graph. However, the gradients of the low frequency linear segment were evaluated and equation $h=-\frac{\mathrm{m}}{4 \pi}$ was used to calculate the depths to top of the causative bodies (deep sources). These depths to the top of the causative magnetic bodies had been reported to vary between 0.52 and $4.38 \mathrm{~km}$ in the study area (Nwankwo et. al., 2008). Figure 4 Shows the Curie-point isotherm estimated from the analysis of frequency of the spectral maximum. The result shows that the Curie isotherm depth varies between 12 and $30 \mathrm{~km}$. The figure shows that in the southern portion of the study area the curiedepth was found above $28 \mathrm{~km}$ while depths less than $14 \mathrm{~km}$ are found in the northern part. Literatures such as Connard et al., 1983; Tsokas et al., 1998; Tanaka et al., 1999; Stampolidis and Tsokas, 2002; Pamukcu, 2004; Dolmaz et al., 2005 indicate that the Curie point depth is greatly dependent upon geological conditions. Curie point depths are shallower than $15 \mathrm{~km}$ for volcanic and geothermal fields, between $15-25 \mathrm{~km}$ for island arcs and ridges, and deeper than $20 \mathrm{~km}$ in plateaus and trenches (Tanaka et al., 1999). Therefore, these areas with variations less than $15 \mathrm{~km}$ maybe recommended for further investigations for geothermal reconnaissance studies.

Estimates of the thickness of the magnetized portion of the earth's crust suggest that there are two types of lower boundaries of the layer of magnetised rocks. One type of boundary corresponds to vertical changes in crustal composition while the other occurs where high temperatures at depth cause the rocks to lose their ferromagnetic properties i. e., below the Curie point Curie-point isotherm (Connard et. al., 1983).

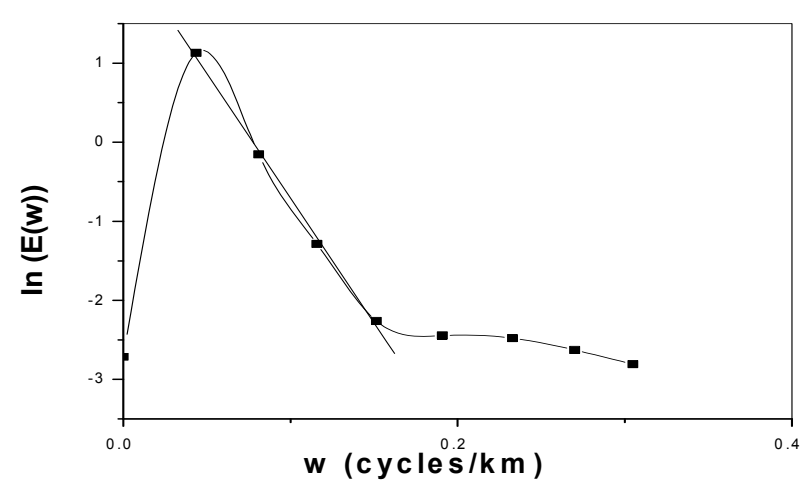

block 4.6

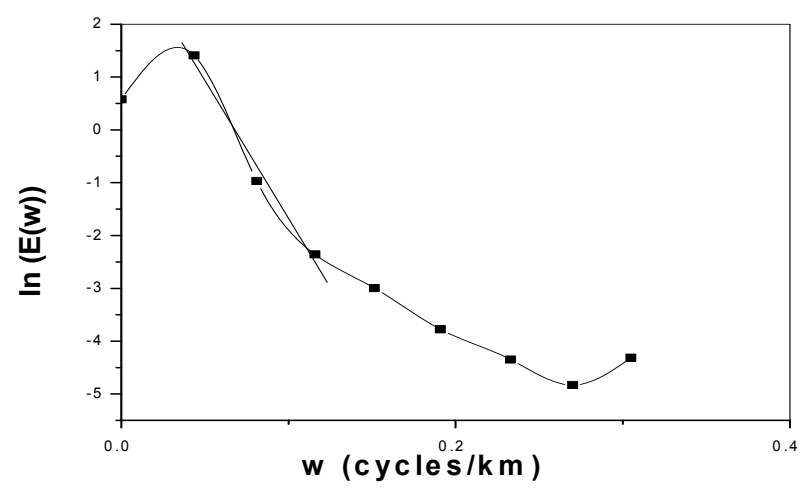

block 4.7

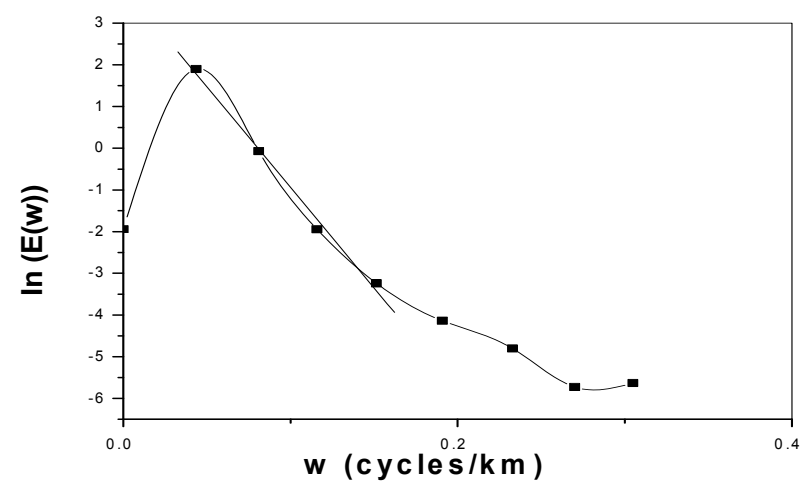

block 4.8

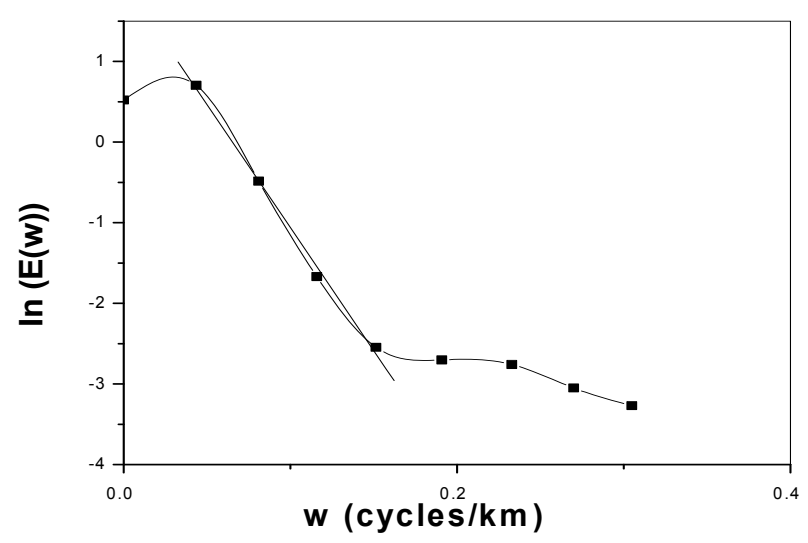

block 5.5 


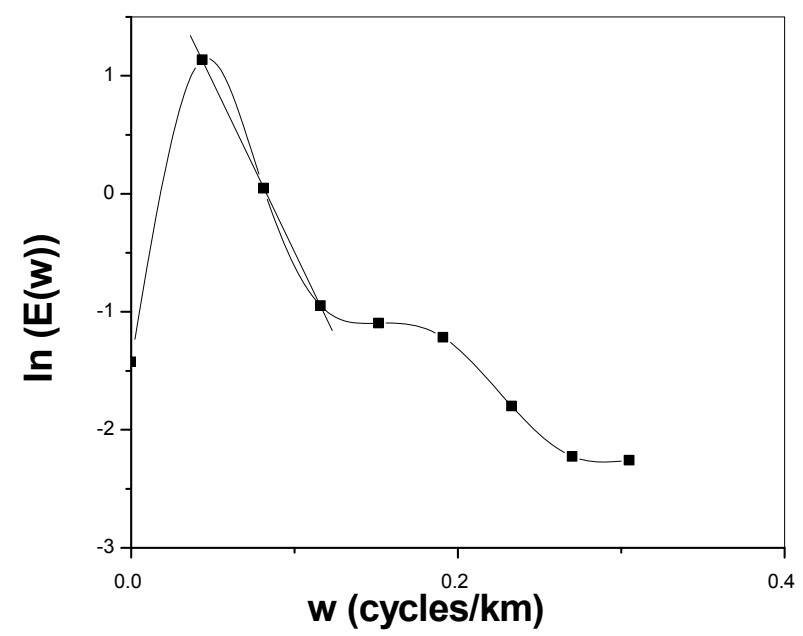

block 6.4

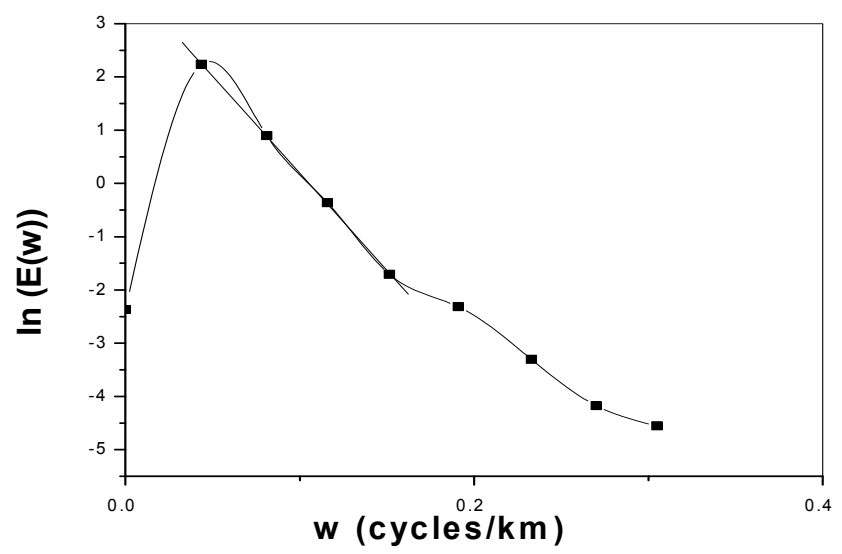

block 6.8

Fig 3: Power spectra for depth estimations of some of the blocks

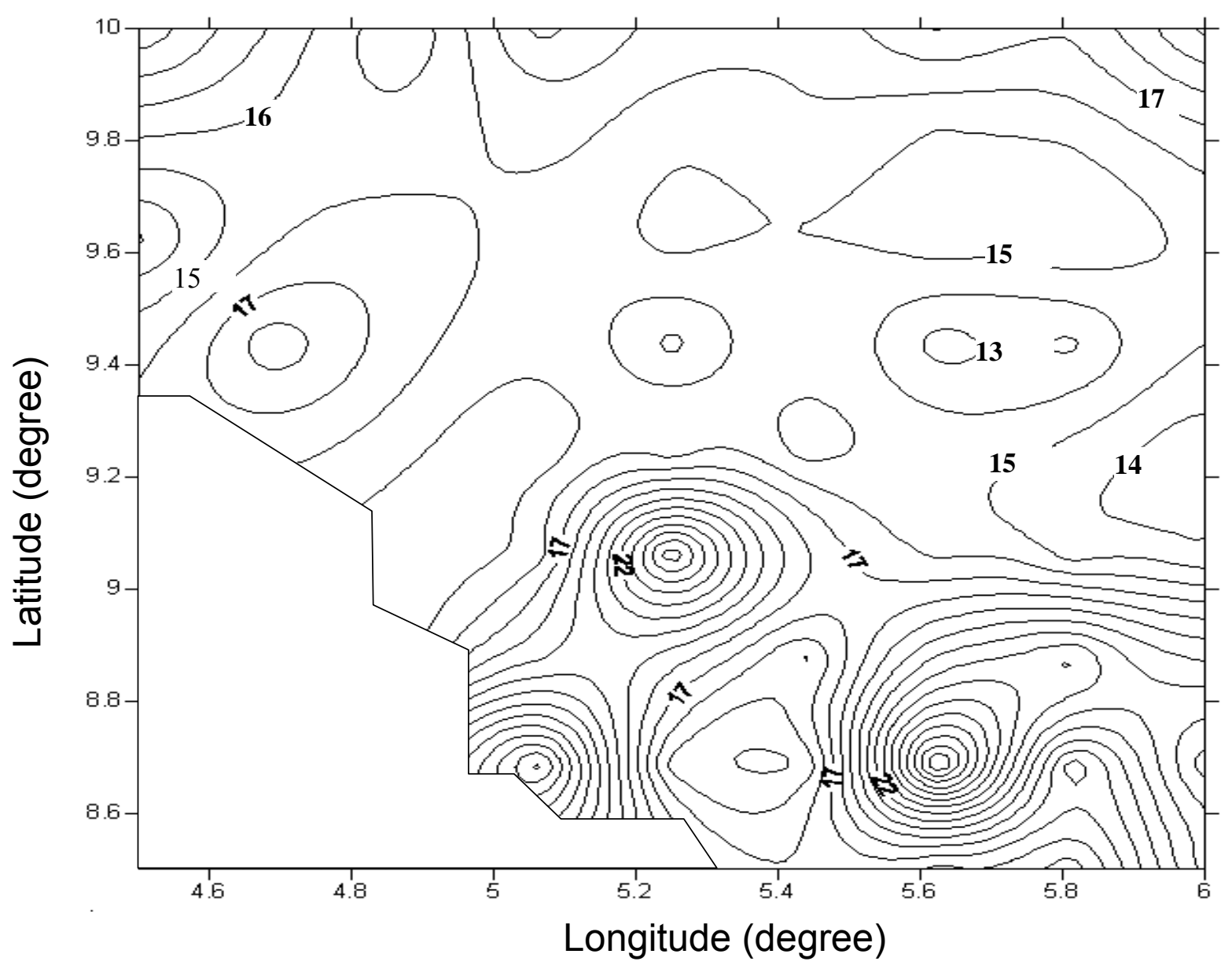

Figure 4: Curie-point isotherm map of the study area. Contour interval is $1.0 \mathrm{~km}$.

The former occurs in area characterised by normal and low heat flow such as the continental shield of Canada (Hall, 1968) and Brazil (Gasparini et al, 1979). The bottoms of the bodies causing regional magnetic anomalies in those areas seem to coincide with intracrustal seismic discontinuities suggesting a lithologic interface. However, the relatively young age of the crust of the Nupe Basin seem to be consistent with the second type of boundary.

\section{CONCLUSION}

The magnetic field observations made at or above the surface of the earth and the magnetisation at the top of the magnetic part of the crust are characterised by relatively short spatial wavelengths, while the magnetic field from the magnetisation at the Curie- point depth will be characterised by longer wavelengths and lower amplitude magnetic anomalies. 
This difference in frequency characteristics between the magnetic effects from the top and bottom of the magnetised layer in the crust can be used to separate magnetic effects at the two depths and to determine the Curie depth. The isotherm has, therefore, been determined in the northern part of the Nupe Basin and it is found to vary between 12 and $30 \mathrm{~km}$. In the southeast and southwest of the study area, the curie-depth was found to be above $28 \mathrm{~km}$, while it was found at depths less than $14 \mathrm{~km}$ in the northeastern and northwestern parts.

\section{ACKNOLEDGEMENTS}

The authors are grateful to the Geological Survey Agency of Nigeria for releasing the aeromagnetic maps. Federal Government of Nigeria Scholarship Board and University of Ilorin for partial scholarships awarded to carry out this work.

\section{REFERENCES}

Adeleye, D. R., 1971. Stratigraphy and sedimentation of the Upper Cretaceous strata around Bida, Nigeria. Ph.D. thesis, University of Ibadan.

Adeleye, D. R., 1973. Origin of Ironstones: An example from Middle Niger Valley, Nigeria. Journal of Sedimentary Petrology, 43: 709-727

Adeleye, D. R., 1974. Sedimentology of the Fluvial Bida Sandstone (Cretaceous), Nigeria. Sedimentary Geology, 12, 1-42.

Adeleye, D. R., 1976. The Geology of Middle Niger Basin. In C. A. Kogbe (Editor), Geology of Nigeria. Elizabethan, Lagos. 283 - 287.

Balogun, O. Y., 2003. Senior Secondary Atlas. $2^{\text {nd }}$ Ed. Longman Nigeria.

Bath, M., 1974. Spectral analysis in Geophysics. Elsevier, Amsterdam.

Bhattacharyya, B. K., 1966. Continuous spectrum of the total magnetic field anomaly due to a rectangular prismatic body, Geophysics, 31, 97121.

Boler, F. M., 1978. Aeromagnetic measurements, magnetic source depths and the curie point isotherm in the Vale-Owyhee, Oregon, M.Sc thesis, Oregon State University, Corvallis.

Connard, G., Couch, R., and Gemperte, M., 1983. Analysis of aeromagnetic measurements from the Cascade Range in Central Oregon, Geophysics 48[3], 376-390.

Dolmaz, M. N., Hirah, Z. M., Ustaomer, T., and Orbay, N., 2005. Curie point depths based on Spectrum Analysis of Aeromagnetic data, West Anatolian extensional province. Turkey. Pure Appl. Geophys. 162, 571-590
Gasparini, P., Mantovani, M. S. M., Corrado, G., and Rapolla, A., 1979. Depth of Curie temperature in continental shields: A compositional boundary. Nature, V. 278, 845-846

Hall, D.H., 1968. A magnetic interpretation method for calculating body parameters for buried sloping steps and thick sheets, Geoexpl., 6, 187-206.

Hildenbrand, T.G., Blakely, R.J., Hinze, W.J., Keller, G.R., Langel, R. A., Nabighian, M., and Roest, W., 1996. Aeromagnetic survey over U.S. to Advance Geomagnetic Research, American Geophysical Union 77[28], 265-268.

Jones, H. A., 1955. The occurance of Oolitic Ironstones in Nigeria: Their Origin, Geological History and Petrology. Oxford D. Phil. Thesis.

Khurana, K.K., 1981. Developing semi-automated processing and Interpretation strategies in magnetics, Ph.D thesis, Osmania University, Hyderabad, India.

Manzella, A., 1999. Geophysical methods in geothermal exploration. Unpbl. Lecture notes of Int. Inst. for geothermal reseach, Pisa, Italy.

Murat, C., 1972. Stratigraphy and Paleogeography of the Cretaceous and lower Tertiary in Southeastern Nigeria. African Geology, T. F. J. Dessauvagie and A. J. Whiteman (Editors), University of Ibadan Press. 251-266.

Nur, A., Ofoegbu, C.O. and Onouha, K. M., 1999. Estimation of the depth to the curie point Isotherm in the upper Benue trough, Nigeria, Nigeria Journal of Mining and Geology, 35[1], 53-60.

Nwankwo, L. I., 2006. A least squares plane surface polynomial fit of two dimensional potential field geophysical data using Matlab. Nig. Journal of Pure and Appl Sci., 21, 2006 - 2013

Nwankow, L. I., Olasenhinde, P. I., and Akoshile, C. O., 2008. Spectral analysis of aeromagnetic anomalies of Northern Nupe Basin, West Central Nigeria. Global Journal of Pure and Appl. Sci.(2), 247252.

Olasehinde, P.I., 1991. A spectral evaluation of the Aeromagnetic anomaly map over part of the Nigerian Basement complex, Ph.D Thesis, unpublished, University of Ilorin.

Onuoha, K.M. and Ofoegbu, C.O., 1988. Subsidence and thermal history of the Dahomey Embayment: Implications for petroleum Exploration, Nigeria Association of petroleum Explorationists Bulletin, 3[2] 131-142.

Pamukcu, O., 2004. Investigation of Geodynamical Structure of Eastern Antatolia using Geophysical Data. PhD Thesis, Izmir: Dokuz lul 
University Graduate School of Natural and Applied Sciences.

Salem, A., Ushijima, K., Elsirafi, A. and Mizanaga, H., 2000. Spectral analysis of aeromagnetic data for geothermal reconnaissance of Quseir area, Northern Red sea, Egypt., Proceedings World Geothermal congress, Kyushu, Japan.

Shuey, R.T., Schellinger, D.K., Tripp, A.C., and Alley, L.B., 1977. Curie depth determination from aeromagnetic spectra, Geophysical Journal of the Royal Astronomical Society, 50, 75-101.

Spector, A., and Grant, F.S., 1970. Statistical models for interpretating aeromagnetic data. Geophysics, 35, 293-302.
Stampolidsis, A and Tsokas, G., 2002. Curie point depth of Macedonia and Thrace, N. Greece, Pure and Applied Geophysics, 159, 1-13

Tanaka, A., Okubo, Y. and Matsubayashi, O., 1999. Curie point depth based on spectrum analysis of the magnetic anomaly data in East and Southeast Asia, Tectonophysics, 306, 461- 470.

Tsokas, G. N., Hansen, R. O., and Fytikas, M., 1998. Curie point depth of the Island of Crete (Greece). Pure and App. Geophy., 152, 747-757 